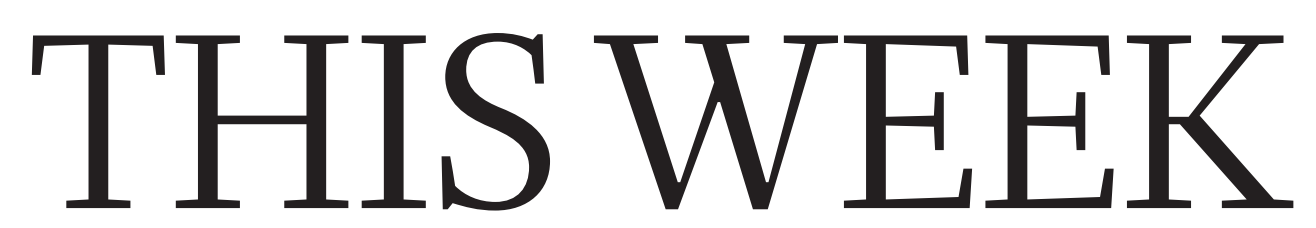

EDITORIALS

EVOLUTION The giraffe's long neck could be its coolest feature $\mathbf{p} 132$
WORLD VIEW Scientists who track reproducibility should succeed $\mathbf{p . 1 3 3}$

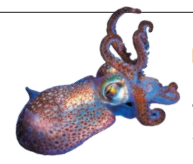

GENE GLOW Marine animals get their colour change from bacteria $\mathbf{p . 1 3 4}$

\title{
Support Ismail Serageldin
}

\section{Egypt's courts must listen to dozens of Nobel prizewinners who have defended the founder of the Alexandria Library.}

$\mathrm{N}$ ext week, an appeals court in Egypt will consider the case of Ismail Serageldin - the retired founding director of the Bibliotheca Alexandrina, or Alexandria Library - who has been convicted of negligent management of the library and sentenced to three-and-a-half years in jail. Some 90 Nobel prizewinners, among others, have signed a letter of concern stating their confidence in Serageldin's integrity. The guilty verdict he received appears to be a miscarriage of justice. The sentence is cruel and unduly harsh. He should go free.

Serageldin disputes the charges, which many fear are politically motivated. He is a forthright proponent of a liberal interpretation of Islam who was appointed by the regime that was overthrown in the 2011 revolution in Egypt, part of the Arab Spring uprising across the Middle East. His case is significant in a region where the hopes of the Arab Spring - including those for a flourishing of education and science - have mostly been dashed.

The political turmoil that followed the uprising against the regime of Egypt's then-president, Hosni Mubarak, was a time for opportunists. Some library workers with grudges, together with those who considered Serageldin a Mubarak stooge, issued more than 100 different accusations against him, ranging from corruption to money laundering. Prosecutors investigated for more than a year. Finding no evidence, they dropped the criminal charges and instead referred three minor accusations of negligent management to an administrative court in 2012.

One of the three charges claims that the 110 permanent library staff (the other 2,300 employees are on renewable contracts) were not given enough to do, and thus their government salaries were being wasted. Another refers to a collective life-insurance policy that had been taken out on behalf of staff, which they objected to. The charge claims that Serageldin, who cancelled the policy after three years, deceived the board of directors into agreeing to repay staff for the contributions they had made. The third charge claims that Serageldin incorrectly negotiated a favourable rent for a cafeteria to operate in the Bibliotheca Alexandrina, without putting it out to public tender.

Nothing happened for a few years while the court waited for the prosecution to submit a technical report about the case, which finally arrived this year. Serageldin says that the report led him to expect a dismissal of all charges. Instead, the court found him guilty. And rather than dishing out the usual modest fine for such cases, it issued a prison sentence, something usually reserved for cases in which negligence leads to loss of life.

The ruling incited a media storm in Egypt and the international academic community. The letter from the Nobel prizewinners declares that they have "confidence in the integrity of Ismail Serageldin" and notes their appreciation of his work in the creation of the library, which they describe as "a beacon of enlightened values for the region and for the world".

The Mediterranean city of Alexandria became the main intellectual and cultural centre of the ancient Hellenic world when the original Bibliotheca Alexandrina was created there in the fourth century BC. Many of the great scientists in the region worked there, from Euclid to Archimedes. It burnt down in the second century AD and scholarship in the region went into decline.

\section{"The library is now a thriving haven of scholarship, rationalism and internationalism."}

Serageldin returned to Egypt from abroad to revive the library in 2001, recreating its spirit for the digital age. $\mathrm{He}$ wanted to do something meaningful for his country and left a prestigious post as vice-president of the World Bank to do so.

The library is now a thriving haven of scholarship, rationalism and internationalism. It has gained respect, nationally as well internationally. During the days of the Arab Spring, impassioned employees and other supporters formed a human chain to protect the facility from being plundered. By contrast, tens of thousands of manuscripts and books were lost in a fire after clashes at the Institut d'Egypte in Cairo. (Fortunately some of the documents, including the 20 scholarly volumes of the historically valuable Description de l'Égypte commissioned by Napoleon in the early nineteenth century, had at least been digitalized at the Bibliotheca Alexandrina.)

Now, it is Serageldin himself who needs support from all who care about what he achieved and what it stands for.

\section{Inflamed brains}

\author{
Studies highlight link between immune \\ response and unusual neural wiring.
}

A century ago, a largely forgotten, worldwide epidemic that would kill nearly a million people was beginning to take hold. Labelled as sleepy sickness - or more properly encephalitis lethargica - the disease caused a number of bizarre mental and physical symptoms and frequently left people in a catatonic state, sometimes for decades. (Oliver Sacks described his successful treatment of some of them in 1969, in the book Awakenings.) The cause has never been officially pinned down, but the most common suggestion is that some kind of infectious agent triggered an autoimmune response, which targeted and inflamed part of the brain.

The role of the immune system in mental disorders is subject to much important research at the moment. The onset of conditions 